\title{
STUDI EKSPERIMENTAL GESER BLOK PADA BATANG TARIK KAYU INDONESIA
}

\author{
Nessa Valiantine Diredja, Bambang Suryoatmono \\ Jurusan Teknik Sipil, Universitas Katolik Parahyangan \\ Jalan Merdeka no.30, Bandung, 40117 \\ e-mail: nessa.valiant@gmail.com
}

\begin{abstract}
ABSTRAK
Salah satu kegagalan yang dapat terjadi pada suatu sambungan baja atau kayu adalah kegagalan geser blok. Penelitian ini mempelajari geser blok pada batang tarik kayu Indonesia. Uji eksperimental pada penelitian ini menggunakan 3 jenis kayu yang berbeda yaitu Sengon, Akasia Mangium, dan Meranti Kuning. Jumlah benda uji yang dibuat adalah 3 benda uji untuk masingmasing jenis kayu. Sambungan kayu adalah sambungan geser ganda dengan menggunakan alat sambung batang baja berulir berdiameter $10 \mathrm{~mm}$. Jarak-jarak baut minimum setiap benda uji dibuat sesuai ketentuan SNI 7973:2013. Berdasarkan hasil perhitungan sambungan geser ganda, didapatkan hasil analisis bahwa kegagalan sambungan kayu yang terjadi adalah kegagalan tumpu pada komponen utama kayu akibat tertekan alat sambung namun hasil pengujian eksperimental menunjukkan terjadinya keruntuhan geser blok pada sambungan kayu. Hasil kuat tarik dari uji eksperimental dan perhitungan menggunakan persamaan pada SNI 7973:2013 memiliki persen beda antara 41,1\% - 50,5\% untuk Sengon, 47,2\% - 48,1\% untuk Akasia Mangium, dan 34,2\% $47,7 \%$ untuk Meranti.
\end{abstract}

Kata kunci: geser blok, batang tarik, sambungan kayu.

\begin{abstract}
One of the failures that can occur in steel or wood connection is block shear failure. This paper examines the block shear in tension member of Indonesian wood. Experimental test in this study used 3 different types of wood, namely Sengon, Acacia Mangium, and Yellow Meranti. The number of the test specimens were 3 for each type of wood. Wood connection was a double shear connection using threaded steel rod with diameter of $10 \mathrm{~mm}$. The minimum bolt distances of each specimen was made in accordance to SNI 7973:2013. Based on double shear connection computation in the standard, the analysis showed that the connection failure is wood bearing in main member but experimental test result indicates the occurrence of block shear failure. Tensile strength results of experimental tests and calculation using equations in SNI 7973:2013 have differences between 41,1\% - 50,5\% for Sengon, 47,2\% - 48,1\% for Acasia Mangium and 34,2\% 47,7\% for Yellow Meranti.
\end{abstract}

Keywords: Block shear, tension member, wood connection.

\section{PENDAHULUAN}

Struktur kayu banyak digunakan untuk rangka kuda-kuda, rangka jembatan, kolom dan balok bangunan serta struktur perancah. Salah satu kekurangan kayu adalah sifatnya yang non homogen, adanya cacat kayu, dan keterbatasan dalam ukuran yang dibutuhkan untuk keperluan struktur bangunan. Untuk mengatasi terbatasnya ukuran kayu, penyambungan kayu merupakan salah satu solusi untuk memenuhi kebutuhan ukuran kayu. 
Kekuatan sambungan kayu dipengaruhi oleh komponen pembentuk sambungan, yaitu jenis kayu yang disambung, alat penyambung dan bentuk sambungan. Perencanaan sambungan kayu terdapat dalam SNI 7973:2013 dan harus memenuhi persyaratan yang ditentukan agar sambungan aman serta tidak mengalami kegagalan. Terdapat beberapa ragam kegagalan yang dapat terjadi pada sambungan kayu akibat beban lateral yaitu kegagalan tumpu pada kayu maupun kegagalan pada alat sambung kayu. Namun salah satu kegagalan yang juga dapat terjadi pada sambungan batang tarik kayu adalah kegagalan geser blok.

Geser blok adalah salah satu kegagalan potensial yang dapat terjadi pada sambungan berlubang. Tegangan tarik terjadi di sepanjang bidang tarik dan tegangan geser terjadi di sepanjang garis longitudinal antar lubang pengencang atau bidang geser. Kekuatan geser blok ditentukan oleh kekuatan tarik pada bidang tarik bersih dan diakumulasikan dengan kekuatan geser minimal pada bidang geser kotor atau bersih. Sehingga dapat diasumsikan bahwa kegagalan terjadi pertama kali pada bidang tarik dan diikuti oleh leleh pada bidang geser. Pada studi ini dilakukan pengujian kuat tarik pada sambungan tarik kayu dengan menggunakan jarak-jarak baut minimum sesuai persyaratan yang terdapat didalam SNI Kayu 7973:2013 dan digunakan jumlah baut minimum pada tiga buah jenis kayu. Dimensi benda uji sambungan batang tarik kayu pada studi ini dapat dilihat pada Gambar 1.

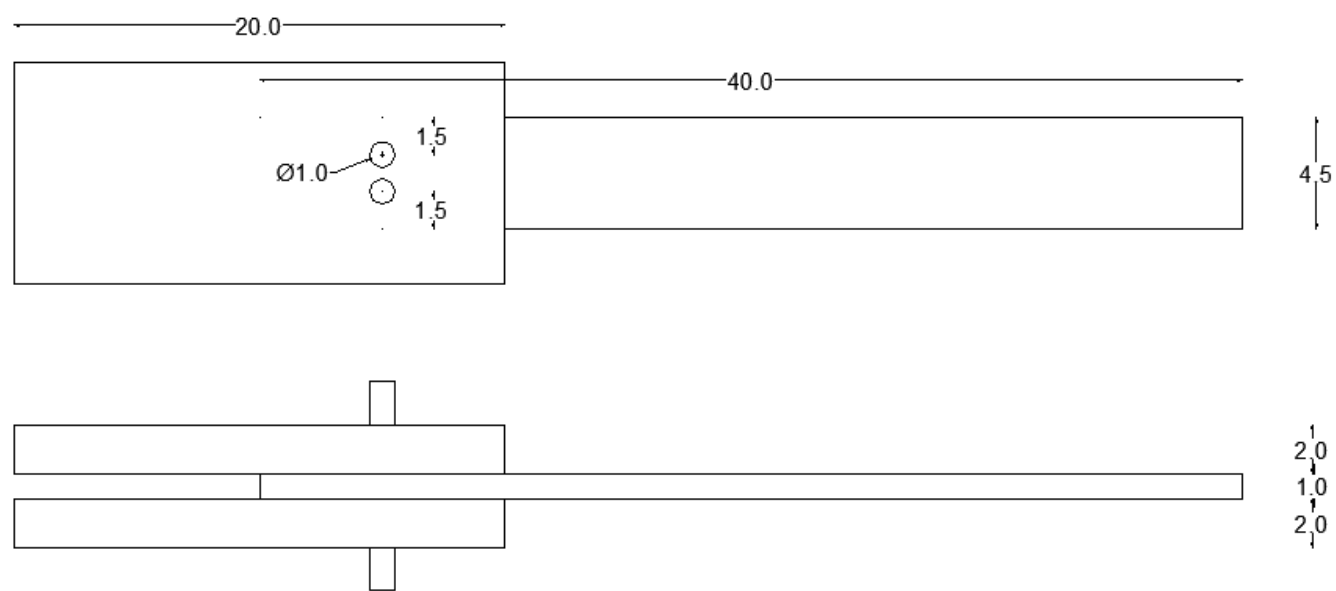

\section{Gambar 1. Dimensi Benda Uji}

\section{TINJAUAN LITERATUR}

Sering kali struktur kayu memerlukan sambungan untuk memperpanjang kayu ataupun sambungan buhul untuk menggabungkan beberapa batang kayu pada satu buhul. Pada umumnya sambungan merupakan bagian yang paling lemah dari suatu struktur 
kayu. Kegagalan pada sambungan lebih sering terjadi dibandingkan dengan kegagalan dari material kayu itu sendiri.

Hal-hal yang dapat menyebabkan rendahnya kekuatan sambungan pada kayu adalah sebagai berikut:

1. Pada bagian buhul atau join terjadi gaya yang sejajar serat pada satu batang, tetapi tidak sejajar serat dengan batang yang lain. Kekuatan kayu yang tidak sejajar serat lebih kecil dibandingkan yang sejajar serat, sehingga kekuatan sambungan harus didasarkan pada kekuatan kayu yang terkecil.

2. Penggunaan alat sambung seperti baut, pasak dan hubungan gigi akan mengurangi luas efektif penampang kayu yang disambung, sehingga kekuatan batang akan lebih rendah bila dibandingkan dengan penampang yang utuh.

3. Kayu memiliki kuat geser sejajar serat yang kecil sehingga dapat terjadi splitting dengan mudah jika beberapa alat sambung dipasang berdekatan. Oleh karena itu, terdapat persyaratan jarak minimum antar alat sambung agar kayu terhindar dari kemungkinan splitting.

\subsection{Keruntuhan Geser Blok}

Keruntuhan geser blok atau dalam SNI 7973:2013 disebut sobek kelompok, dikenal sebagai bentuk keruntuhan potensial yang dapat menentukan kapasitas beban dari sambungan atau komponen struktur. Blok yang terhubung dengan pelat buhul dibatasi oleh garis lintasan keruntuhan di antara lubang-lubang pengencang, dengan dalam mekanisme keruntuhannya tegangan tarik terjadi di sepanjang garis transversal (bidang tarik) dan tegangan geser terjadi di sepanjang garis longitudinal antar lubang baut (bidang geser). Mekanisme keruntuhan geser blok pada sambungan dapat dilihat pada Gambar 2 dan Gambar 3.
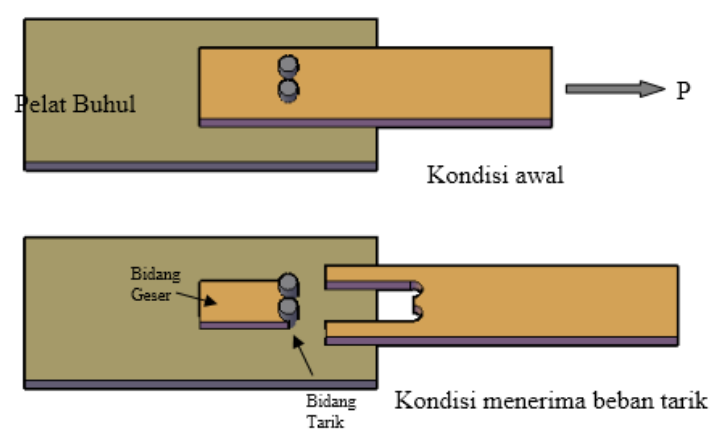

\section{Gambar 2. Mekanisme Keruntuhan Geser Blok Pada Sambungan}



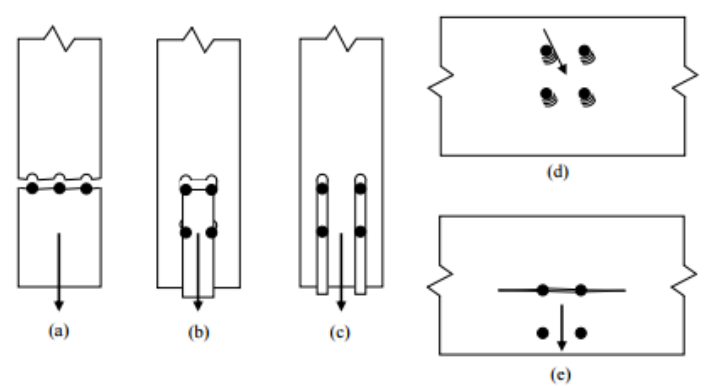

\section{Gambar 3. Mode Kegagalan Untuk Kayu Dengan Sambungan Baut (a). Tarik (b) Geser Blok (Sobek Kelompok) (c) Geser (sobek) (d) Tumpu (e) Splitting}

\section{[Quennevile,2008]}

Menurut SNI 7973-2013, geser blok pada kayu atau kapasitas sobek kelompok dapat dihitung dengan menggunakan persamaan sebagai berikut:

$$
Z_{G T}{ }^{\prime}=\frac{Z_{R T-1}{ }^{\prime}}{2}+\frac{Z_{R T-n}{ }^{\prime}}{2}+F_{t}{ }^{\prime} A_{\text {group-neto }}
$$

dengan:

$$
\begin{array}{ll}
Z_{G T}, & =\text { Kapasitas sobek kelompok terkoreksi } \\
Z_{R T-1}, & =\text { Kapasitas sobek terkoreksi baris } 1 \text { dari pengencang } \\
& \text { yang membatasi luas kelompok kritis } \\
Z_{R T-n}, & =\text { Kapasitas sobek terkoreksi baris } \mathrm{n} \text { dari pengencang } \\
& \text { yang membatasi luas kelompok kritis } \\
A_{\text {group-neto }} & =\text { Luas penampang kelompok kritis antara baris } 1 \text { dan } \mathrm{n}
\end{array}
$$

Kapasitas geser atau sobek terkoreksi dapat dihitung dengan persamaan sebagai berikut:

$$
Z_{R T}{ }^{\prime}=n_{i} \frac{F_{v}{ }^{\prime} A_{\text {critical }}}{2}
$$

dengan: $\quad Z_{R T}{ }^{\prime} \quad=$ kapasitas sobek terkoreksi baris $\mathrm{i}$

$F_{v}{ }^{\prime} \quad=$ nilai desain geser terkoreksi sejajar serat

$A_{\text {critical }}=$ luas geser minimum setiap pengencang pada baris i

$n_{i} \quad=$ banyak pengencang di baris $\mathrm{i}$

dengan mengasumsikan satu garis geser di setiap sisi baut pada sebuah baris (sebagaimana diamati pada uji sambungan baut), Persamaan (2) menjadi:

$$
Z_{R T}{ }^{\prime}=n_{i} F_{v}{ }^{\prime} S_{\text {critical }}
$$

dengan: $\quad S_{\text {critical }}=$ jarak minimum di baris i yang diambil dari yang terkecil antara jarak ujung atau jarak antar pengencang di baris i

$t \quad=$ ketebalan komponen struktur 
Dalam persamaan (2) diasumsikan bahwa tegangan geser yang terjadi bervariasi dari nilai maksimum $f_{v}=F_{v}$ ' ke nilai $f_{v}=0$ di sepanjang setiap garis geser di antara pengencang dalam satu baris dan bahwa perubahan regangan/tegangan geser adalah linier di sepanjang garis geser seperti yang terlihat pada Gambar 4. Distribusi tegangan berbentuk segitiga yang dihasilkan di setiap garis geser antara pengencang di satu baris memberikan tegangan geser sama dengan setengah dari tegangan geser desain terkoreksi, $\mathrm{F}_{\mathrm{v}}{ }^{\prime} / 2$, sebagaimana ditunjukkan di dalam persamaan (2). Asumsi ini digabungkan dengan konsep luas kritis untuk mengevaluasi tegangan di kelompok pengencang dan sangat cocok dengan hasil-hasil tes pada sambungan dengan baut. [SNI 7973:2013]

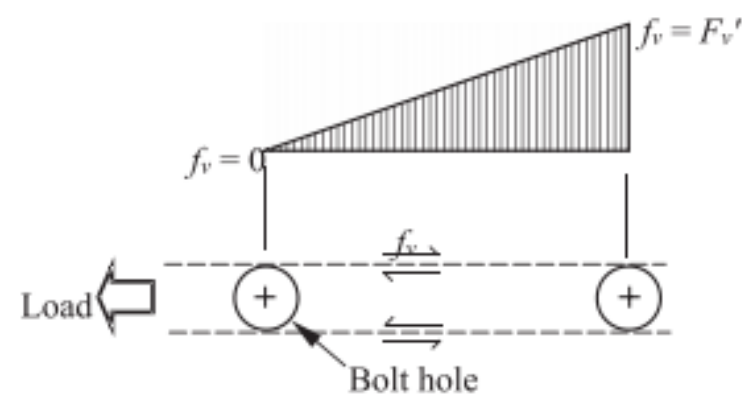

\section{Gambar 4. Asumsi Distribusi Tegangan Geser Antara Baut Dalam Satu Baris} [Taylor,2015]

\section{UJI EKSPERIMENTAL}

Pengujian sambungan tarik geser ganda dilakukan menggunakan Universal Testing Machine pada tiga buah jenis kayu yaitu kayu Sengon, Akasia Mangium, dan Meranti Kuning. Pada penelitian ini digunakan batang baja berulir berdiameter $10 \mathrm{~mm}$ sebagai pengencang tanpa menggunakan mur dan ring. Sambungan direncanakan menggunakan jarak-jarak minimum, baik jarak ujung, jarak tepi, maupun jarak antar baut. Ukuran ring dan mur yang lebih besar dibandingkan dengan jarak-jarak yang direncanakan tersebut menyebabkan ring dan mur tidak dapat dipergunakan.

Pada saat pengujian benda uji diposisikan pada mesin UTM dengan bantuan pelat baja dan dikunci menggunakan sekrup pada bagian komponen samping guna menjepit sambungan kayu karena keterbatasan lebar UTM, sedangkan bagian komponen utama dimasukan langsung ke dalam penjepit UTM seperti yang terlihat pada Gambar 5. Pengujian tarik lalu dimulai dan dilakukan hingga benda uji mengalami keruntuhan. Kurva hubungan antara kuat tarik dan peralihan serta kondisi hasil akhir pengujian pada masing-masing benda uji dapat dilihat pada Gambar 6 sampai dengan Gambar 11. 


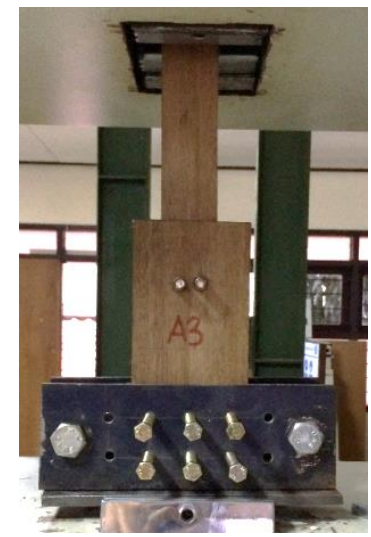

Gambar 5. Pelat Baja Penjepit Sambungan Kayu pada Mesin UTM
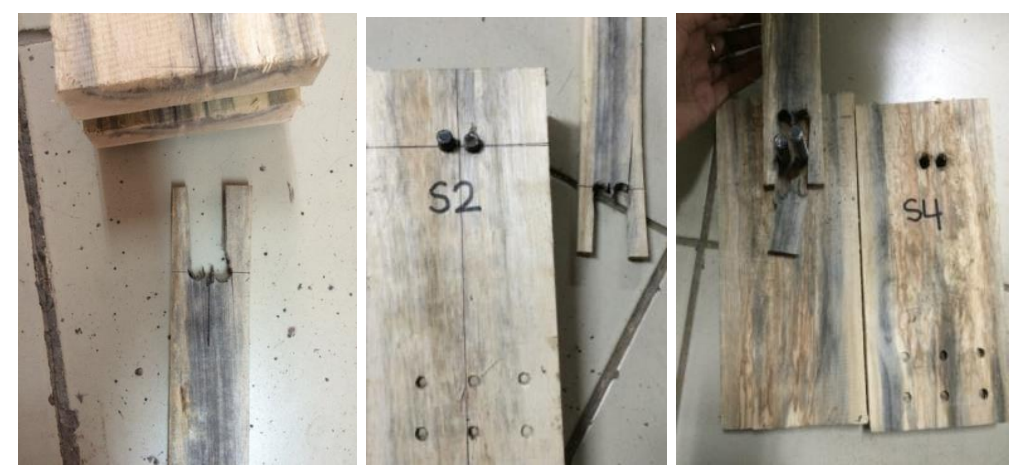

Gambar 6. Kondisi Benda Uji 1, 2, dan 3 Kayu Sengon Setelah Terjadi Keruntuhan

Pada Gambar 6, terlihat bahwa benda uji 1, 2 dan 3 kayu Sengon mengalami keruntuhan geser blok. Dari hasil pengujian didapatkan kurva hubungan beban dan peralihan sambungan tarik kayu Sengon seperti yang ditunjukkan pada Gambar 7. Melalui kurva hubungan beban dan peralihan ini didapatkan kuat tarik sambungan dengan mengambil beban maksimum yang terjadi pada masing-masing benda uji.

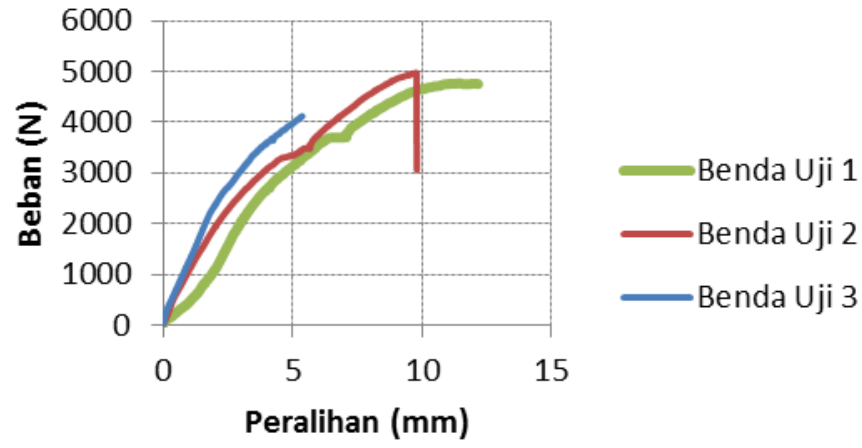

Gambar 7. Kurva Hubungan Antara Beban dan Peralihan Sambungan Batang Tarik Kayu Sengon 


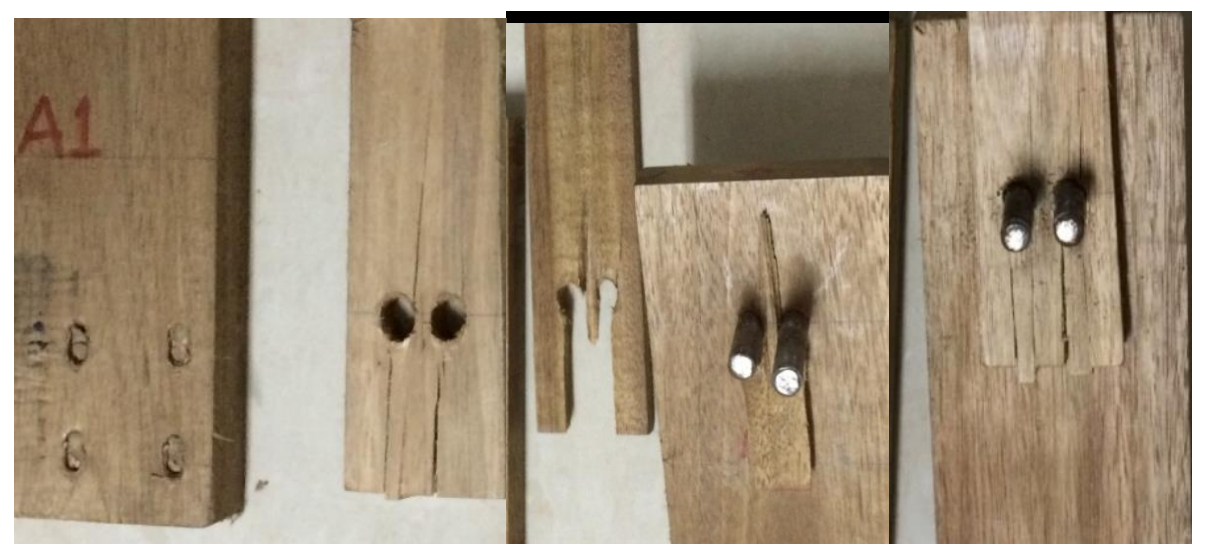

Gambar 8. Kondisi Benda Uji 1, 2, dan 3 Kayu Akasia Mangium Setelah Terjadi Keruntuhan

Pada Gambar 8, terlihat bahwa benda uji 1 dan benda uji 2 sambungan kayu Akasia Mangium mengalami kegagalan geser blok dengan tegangan tarik yang tidak seragam dilihat dari kegagalan tarik yang berbentuk segitiga, sedangkan benda uji 3 mengalami kegagalan geser. Kurva hubungan beban dan peralihan sambungan kayu Akasia Mangium ditunjukkan pada Gambar 9.

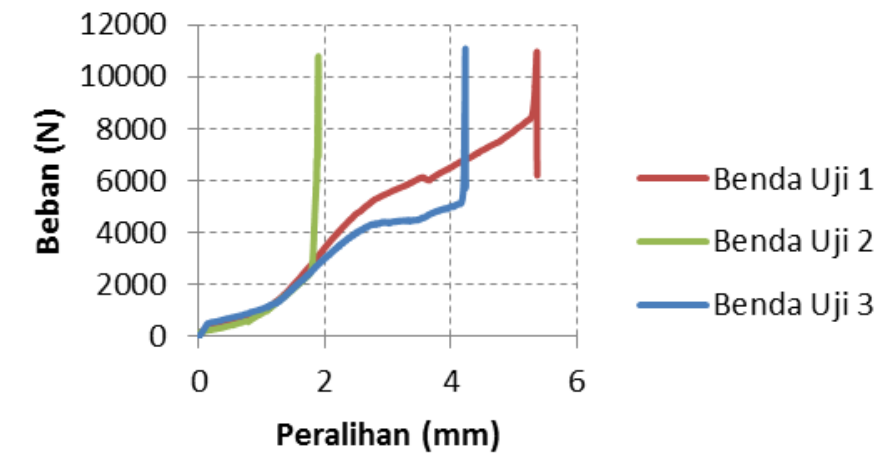

\section{Gambar 9. Kurva Hubungan Antara Beban dan Sambungan Batang Tarik Kayu Akasia Mangium}

Hasil pengujian tarik sambungan kayu Meranti menunjukkan terjadinya kegagalan geser blok pada benda uji 1, 2 dan 3. Kegagalan geser blok ini terjadi dengan tegangan tarik yang tidak seragam seperti yang ditunjukkan pada Gambar 10. Kurva hubungan beban dan peralihan sambungan kayu Meranti dapat dilihat pada Gambar 11. 

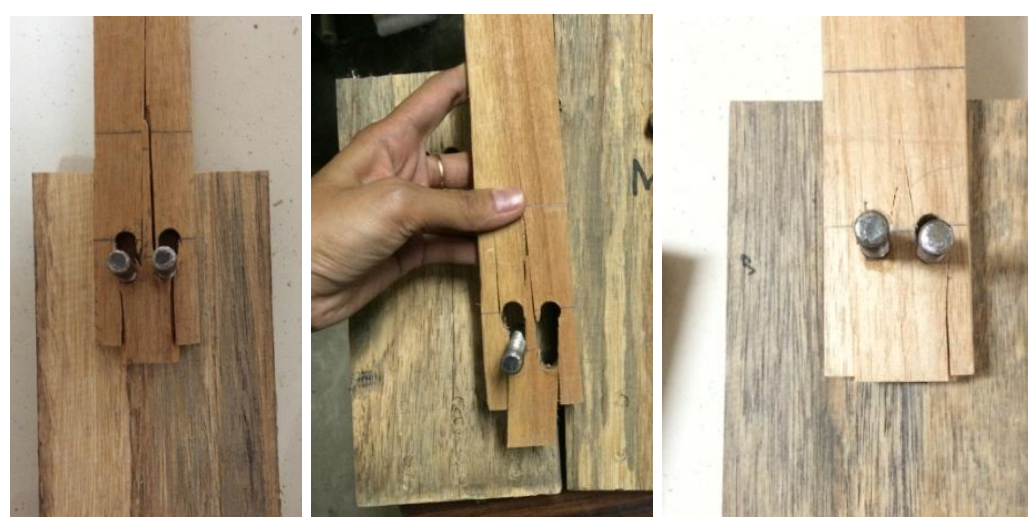

\section{Gambar 10. Kondisi Benda Uji 1, 2, dan 3 Kayu Meranti Setelah Terjadi \\ Keruntuhan}

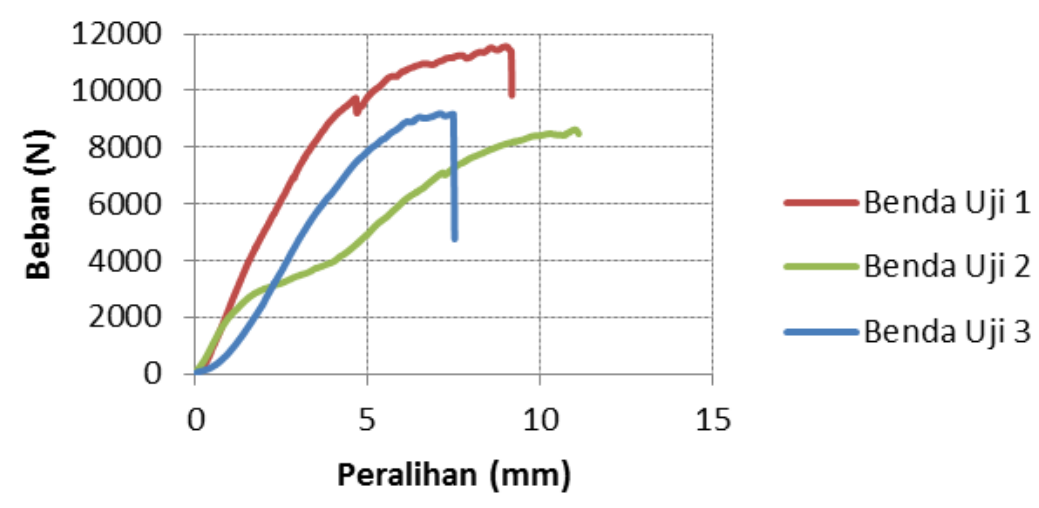

\section{Gambar 11. Kurva Hubungan Antara Beban dan Peralihan Sambungan Batang Tarik Kayu Meranti}

\section{ANALISIS HASIL UJI EKSPERIMENTAL}

Melalui pengujian tarik sambungan kayu, didapatkan kuat tarik dari masingmasing sambungan seperti yang ditunjukkan pada Tabel 1. Menurut perhitungan sambungan geser ganda berdasarkan SNI 7973:2013, kegagalan yang akan dialami oleh sambungan tarik kayu adalah kegagalan tumpu pada kayu akibat tertekan alat sambung pada komponen utama. Namun berdasarkan uji eksperimental, kegagalan yang dialami oleh sambungan kayu adalah kegagalan geser blok. Geser blok adalah kondisi batas dengan tahanan ditentukan oleh jumlah kuat geser dan kuat tarik pada segmen yang saling tegak lurus. Hasil perhitungan analisis kuat nominal geser blok kayu dengan menggunakan persamaan (1) dapat dilihat dalam Tabel 2. 
Tabel 1. Kuat Tarik Sambungan Kayu

\begin{tabular}{|c|c|c|c|}
\hline Jenis Kayu & SG & Kuat Tarik (N) & Mode Kegagalan \\
\hline \multirow{3}{*}{ Sengon } & \multirow{3}{*}{0.271} & 4768.70 & Geser Blok \\
\hline & & 4972.34 & Geser Blok \\
\hline & & 4178.25 & Geser Blok \\
\hline \multirow{3}{*}{$\begin{array}{c}\text { Akasia } \\
\text { Mangium }\end{array}$} & \multirow{3}{*}{0.698} & 10967.63 & Geser Blok \\
\hline & & 10791.10 & Geser Blok \\
\hline & & 11087.58 & Geser \\
\hline \multirow{3}{*}{ Meranti } & \multirow{3}{*}{0.729} & 11562.84 & Geser Blok \\
\hline & & 10143.85 & Geser Blok \\
\hline & & 9189.86 & Geser Blok \\
\hline
\end{tabular}

Tabel 2. Hasil Analisis Kuat Nominal Geser Blok Kayu Menggunakan Persamaan

(1)

\begin{tabular}{cccccccc}
\hline Jenis Kayu & $\begin{array}{c}\mathrm{F}_{\mathrm{v}} \\
(\mathrm{MPa})\end{array}$ & $\begin{array}{c}\mathrm{F}_{\mathrm{t}} \\
(\mathrm{MPa})\end{array}$ & $\begin{array}{c}\mathrm{Z}_{\mathrm{NT}}{ }^{\prime} \\
(\mathrm{N})\end{array}$ & $\mathrm{Z}_{\mathrm{RT}-1}{ }^{\prime}(\mathrm{N})$ & $\begin{array}{c}\mathrm{Z}_{\mathrm{RT}-2}{ }^{\prime} \\
(\mathrm{N})\end{array}$ & $\begin{array}{c}\mathrm{Z}_{\mathrm{RT}}{ }^{\prime} \\
(\mathrm{N})\end{array}$ & $\begin{array}{c}\mathrm{Z}_{\mathrm{GT}}{ }^{\prime} \\
(\mathrm{N})\end{array}$ \\
\hline Sengon & 2.3 & 26.19 & 6547.5 & 1150 & 1150 & 2300 & 2459.5 \\
\hline $\begin{array}{c}\text { Akasia } \\
\text { Mangium }\end{array}$ & 4.19 & 72,04 & 18010 & 2095 & 2095 & 4190 & 5697 \\
\hline Meranti & 4.67 & 74.1 & 18525 & 2337.5 & 2337.5 & 4675 & 6042.5 \\
\hline
\end{tabular}

Perbedaan besar kuat tarik sambungan antara hasil eksperimental dan dengan menggunakan persamaan (1) ditunjukkan pada Tabel 3

Tabel 3. Perbandingan Hasil Analisis Perhitungan Geser Blok Menggunakan Persamaan (1) dan Uji Eksperimental

\begin{tabular}{|c|c|c|c|c|c|}
\hline $\begin{array}{l}\text { Jenis } \\
\text { Kayu }\end{array}$ & $\begin{array}{c}\text { Benda } \\
\text { Uji }\end{array}$ & $\begin{array}{c}\text { Mode } \\
\text { Kegagalan }\end{array}$ & $\mathrm{P}_{\text {eksperimental }}(\mathrm{N})$ & $\mathrm{P}_{\text {persamaan (1) }}(\mathrm{N})$ & $\%_{\text {Beda }}$ \\
\hline \multirow{3}{*}{ Sengon } & 1 & Geser Blok & 4768.70 & 2459.50 & -48.4 \\
\hline & 2 & Geser Blok & 4972.34 & 2459.50 & -50.5 \\
\hline & 3 & Geser Blok & 4178.25 & 2459.50 & -41.1 \\
\hline \multirow{2}{*}{$\begin{array}{c}\text { Akasia } \\
\text { Mangium }\end{array}$} & 1 & Geser Blok & 10967.63 & 5697.00 & -48.1 \\
\hline & 2 & Geser Blok & 10791.10 & 5697.00 & -47.2 \\
\hline \multirow{3}{*}{ Meranti } & 1 & Geser Blok & 11562.84 & 6042.50 & -47.7 \\
\hline & 2 & Geser Blok & 10143.85 & 6042.50 & -40.4 \\
\hline & 3 & Geser Blok & 9189.86 & 6042.50 & -34.2 \\
\hline
\end{tabular}

Berdasarkan hasil pengujian, benda uji 3 sambungan kayu Akasia Mangium mengalami kegagalan geser sehingga tidak diperhitungkan didalam analisis geser blok. 
Pada Tabel 3 dapat dilihat bahwa hasil kuat tarik dari uji eksperimental dan perhitungan menggunakan persamaan (1) memiliki persen beda antara $41,1 \%-50,5 \%$ untuk kayu Sengon, 47,2\% - 48,1\% untuk kayu Akasia Mangium, dan 34,2\% - 47,7\% untuk kayu Meranti. Hasil ini menunjukkan bahwa persamaan (1) memiliki kuat tarik hampir setengah lebih kecil dibandingkan hasil uji eksperimental.

\subsection{ANALISIS HUBUNGAN ANTARA KUAT TARIK DAN BERAT JENIS}

Untuk mengetahui korelasi antara kuat tarik dan berat jenis dari masing-masing jenis kayu, dibuat suatu kurva hubungan antara kuat tarik dan berat jenis seperti yang terlihat pada Gambar 12. Pada Gambar 12 terlihat bahwa semakin besar berat jenis maka semakin besar pula kuat tarik yang terjadi, baik melalui hasil uji eksperimental maupun berdasarkan perhitungan menggunakan persamaan (1). Namun, pada Gambar 13 yaitu kurva hubungan antara perbandingan $\mathrm{P}_{\text {eksperimental }}$ dan $\mathrm{P}_{\text {persamaan(1) }}$ dengan berat jenis terlihat bahwa berat jenis tidak memiliki pengaruh terhadap perbandingan $\mathrm{P}_{\text {eksperimental }}$ dan $\mathrm{P}_{\text {persamaan(1). }}$.

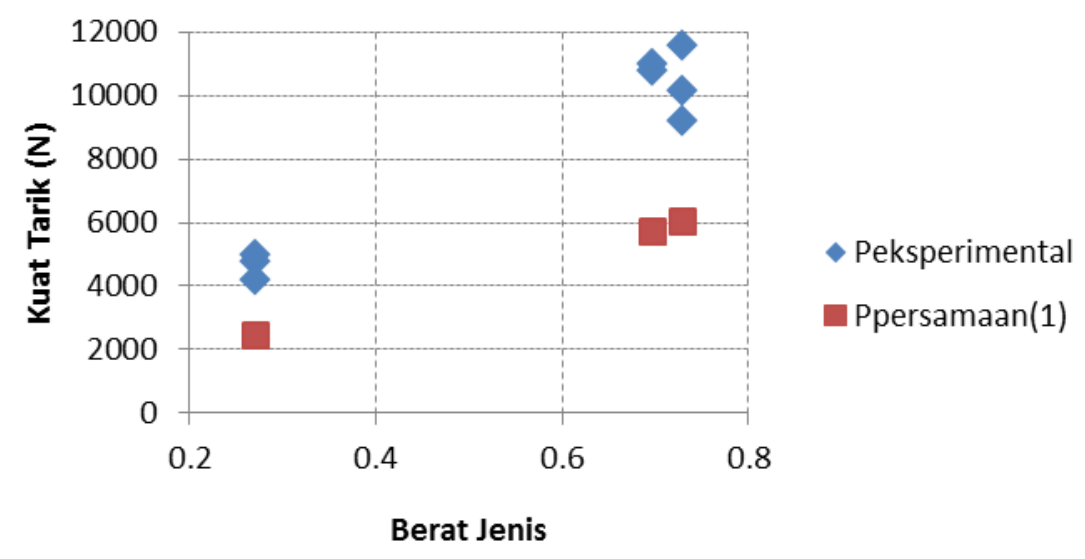

Gambar 12. Kurva Hubungan Antara Kuat Tarik dan Berat Jenis

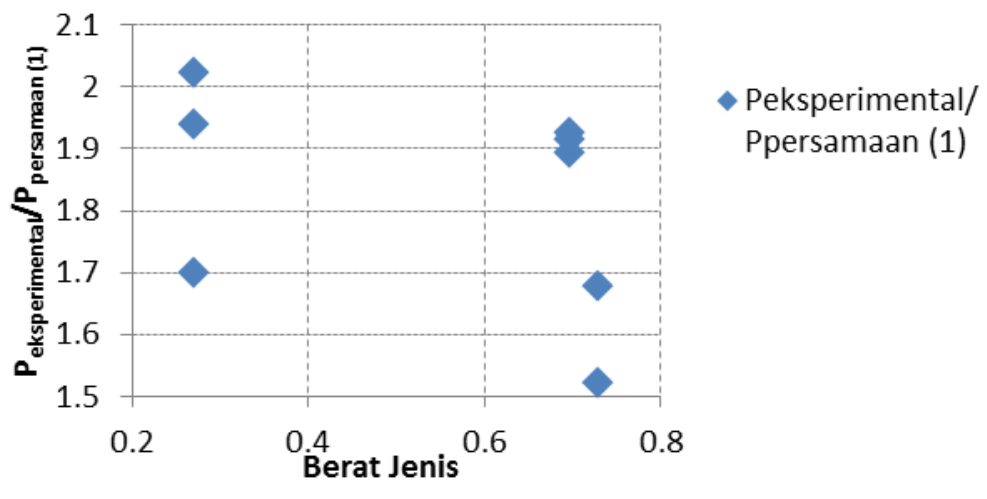

Gambar 13. Kurva Hubungan Antara $P_{\text {eksperimental }} / P_{\text {persamaan(1) }}$ dan Berat Jenis 


\section{KESIMPULAN}

Setelah dilakukan analisis kuat tarik sambungan kayu geser ganda menggunakan alat sambung batang baja berulir, dapat ditarik beberapa kesimpulan sebagai berikut:

1. Melalui analisis menggunakan persamaan SNI 7973:2013 didapatkan hasil bahwa kegagalan sambungan kayu yang akan terjadi adalah kegagalan tumpu pada kayu utama (batang tengah) akibat tertekan alat sambung. Namun, berdasarkan uji eksperimental kuat tarik sambungan, kegagalan yang dialami oleh sambungan batang tarik kayu adalah kegagalan geser blok. Kegagalan geser blok ini terjadi meskipun jarak-jarak yang digunakan telah memenuhi persyaratan jarak minimum yang terdapat pada SNI 7973:2013.

2. Hasil kuat tarik uji eksperimental dan perhitungan menggunakan persamaan pada SNI 7973:2013 memiliki persen beda antara 41,1\% - 50,5\% untuk kayu Sengon, 47,2\% - 48,1\% untuk kayu Akasia Mangium, dan 34,2\% - 47,7 \% untuk kayu Meranti. Uji eksperimental menghasilkan kuat tarik yang lebih besar dibandingkan persamaan pada SNI 7973:2013. Hal ini disebabkan karena pada persamaan SNI 7973:2013 diasumsikan distribusi yang dihasilkan di setiap garis geser antara pengencang di satu baris memberikan tegangan geser sama dengan setengah dari tegangan geser desain, $\mathrm{F}_{\mathrm{v}} / 2$.

3. Dari kurva hubungan antara perbandingan $P_{\text {eksperimental }}$ dan $P_{\text {persamaan(1) }}$ dengan berat jenis menunjukkan bahwa berat jenis tidak memiliki pengaruh terhadap perbandingan $\mathrm{P}_{\text {eksperimental }}$ dan $\mathrm{P}_{\text {persamaan(1). }}$.

\section{SARAN}

Dilakukan penelitian lebih lanjut dengan jenis sambungan, jenis kayu, jenis pengencang, jumlah dan jarak pengencang yang berbeda.

\section{DAFTAR PUSTAKA}

1. Breyer, D.E. et.al. (2015). Design of Wood Structures $7^{\text {th }}$ Edition. McGraw-Hill. New York.

2. Quenneville, Pierre. Design of Bolted Connections: A Comparison of a Proposal an Various Existing Standards. NZ Timber Design Journal Vol. 17 Issue 2.

3. SNI 7973:2013. (2013). Spesifikasi Desain untuk Konstruksi Kayu. Badan Standarisasi Nasional. 
4. Taylor, Robert J., Line, Philip., and Showalter, John. (2015). Don't Let Your Wood Connections Get Stressed Out. (online). (http://www.GoStructural.com/, diakses 20 April 2016)

5. Wood as an Engineering Material. (2010). United State Department of Agriculture Forest Service. Madison, Wisconsin. 